\title{
О единственном сборнике стихотворений прозаика Юрия Домбровского «Меня убить хотели эти суки»
}

\author{
Ирина Захариева \\ (София, Болгария)
}

Юрий Домбровский (1909-1978), на год не доживший до своего семидесятилетия, один из тех, кто является украшением человеческого рода. Выходец из семьи интеллигентов (отецадвокат, матьбиолог), москвич по рождению. Его школьные годы тесно связаны с топонимом московского Арбата. Он мог бы сказать о себе словами песни Булата Окуджавы: «Ах, Арбат, мой Арбат, тымое отечество, / никогда до конца не пройти тебя!». ${ }^{1}$ В семейной среде и в школе обнаружилось влечение юного Домбровского к литературе. Высшее образование он получил в Москве на Высших литературных курсах (названных «брюсовскими»). На курсах учились в одно время с ним будущие известные представители литературыписатель-духовидец Даниил Андреев, а также поэты Арсений Тарковский и Мария Петровых, вынужденные писать «в стол» (без надежды на публикацию) в течение нескольких десятилетий советского периода.

Впервые Домбровский был привлечен к суду в 23-лет-нем возрастеарестован за вольномыслие и выслан в Казахстан, в Алма-Ату. Там, работая в Центральном музее казахской столицы, определил свои интересы в области археологии и был прозван «хранителем древностей», поскольку в любое дело привык вкладывать пассионарную страсть.

Домбровскийавтор четырех романов: «Державин», «Обезьяна приходит за своим черепом», «Хранитель древностей» и «Факультет ненужных вещей».

1 OKUDŽAVA, B.: Zamok nadeždy. Moskva, 2008, s. 19. 
Всегда считал себя прозаиком, но страстно увлекался поэзией. К любимым поэтам относил Вл. Ходасевича, Н. Гумилева, М. Цветаеву. А из поэтов прошлого перечитывал знаменитых Г. Р. Державина, А. С. Пушкина и менее известного поэта первой половины XIX-го века Дмитрия Веневитинова.

Во время второго ареста 1939-1942 годов его засадили в колымские лагеря. Именно тогда, оказавшись в ледяной пустыне Колымы, писатель взялся за перо под напором желания не просто излагать переживаемое, но воспользоваться средствами поэтического языкавозбудителя эмоций.

В годы работы над арестантской тетрадью стихотворений он настроился на преодоление настроений изоляции от жизни. Оформилась поэтическая книга с трудной судьбой и экспрессивным заглавием «Меня убить хотели эти суки» объект настоящего анализа. ${ }^{2}$

В пространстве текста творец оказался наедине с современностью, ведущей в историю, наедине с мучительным мигом и нейтральной вечностью, с теснотой тюремной камеры и ширью мироздания. В его воображении исчезали ненавистные очертания тюрьмы и открывалась безграничность вселенной.

Опубликовать без промедлений ему удалось только маленькую поэму «Каменный топор» в журнале «Литературный Казахстан» (1939). Оставшийся запас стихов продолжал храниться в рукописях до конца XX-го века.

Каменный топор, как необходимая древнему человеку вещь, для автораисходная принадлежность истории, движущейся «через смерти, дожди и увечья» (с. 11). Память пишущего, опираясь на слышанные в детстве предания, сохраняет «вселенную ... в дыму». Лирический персонаж мысленно созерцает стихийно бушующий на земле огонь и потонувшие во тьме пещеры. От обозреваемой им земной панорамы исходит космическое великолепие: «Солнце маревом пожара / Наклонилось над землей» (с. 12). В распахнутой взору автора всемирной перспективе субъект обращен к «поющему мирозданию» (с. 13). Наибольший интерес Домбровского в стихах вызывает человек, уловленный во всемирной и космической перспективе.

Мировая историяодна из привычных тем в его текстах. Сознавая, что история перенасыщена войнами («на земле убийстворемесло»), поэт призывает задуматься об итогах опустошительных войн, отделенных от переживаемого времени столетиями (в стихотворении 1940 года «О, для чего ты погибала, Троя...»). Потери невосполнимы: «Истлели все: и рыцари, и Боги, растертые в один летучий прах...». От войн остался лишь «пустынный вихрь», уничтоживший людей в расцвете лет и сил. И неважно, какие онибезвестные жертвы или

2 DOMBROVSKIJ, Ju.: Menja ubit' choteli èti suki. Moskva, 1997, s. 11. В дальнейшем стихотворения и высказывания Домбровского цитируются по данному изданию с указанием страницы в тексте. 
же обладатели мифологических имен («И словно пыль скрипят под сапогами / Мозг Одиссея и Елены грудь»).

Лирический герой со свойственной ему пытливостью мысли интересуется и скрытыми в древних мифах «тайнами бытия»: «Как человеком сделалась змея, / Накормленная райскими плодами» в стихотворении «Медлительный еврей с печальными глазами...». Интерес к истории и мифологии совмещается у него с желанием насладиться мировым искусством («Анри Руссо»). У французского художника он распознает яркий колорит экзотических объектов: «Там есть еще багровый жирный цвет. / Страстей и чувств кровавые изнанки. / Там так нежна фигура таитянки, / Струящая почти лиловый цвет...».

В стихотворение «Анри Руссо» проникает струя лиризма, ведущая тему воспоминаний о детстве: «О, далекий край земли, / Где по ровной глади / Проплывают корабли в детские тетради!» Припоминаемые детские рисункивоплощенная непосредственность. Но и детские рисунки приводят автора к кумиру-художнику: «Ах, угодны для души / Ваши мне карандаши! / ... / Храмы голубые, / Дамы молодые, / Небо, в небе колесо.../ Вы создатель их, Руссо...».

Поэтпоклонник французского художника продолжает держать в своем сознании Анри Руссо и при посещении выставки талантливейшего художника Грузии Пиросманишвили. Последний именуется в частном письме «нашим кавказским Анри Руссо» (с. 23). Прозаик особенно уважает профессию художника. В романе «Факультет ненужных вещей» (1964-1975) Домбровский запечатлел самую важную, с его точки зрения, фигуру: это художник Сергей Калмыков «гений первого ранга Земли и всей Вселенной». В финале романа «мудрые марсиане» с их «сверхмощными устройствами» увидели с высоты небес чудо, порожденное фантазией художника. Калмыков имел смелость утверждать радость на холсте и в страшном 1937 году. ${ }^{3}$

И в условиях концентрационного лагеря поэт не мог обходиться без вечной темы любви. Тема минувшей любви занимает его в стихотворении со значащим названием «Реквием» и с подключением эпиграфа из французского поэта XV века Франсуа Вийона: «Где ты, где ты, о прошлогодний снег?». Лирического персонажа волнует рубеж чувство/чувственность он остается на страже космического чувства любви. В стихотворении рассказано, как чувство, взлетавшее на лебяжьих крыльях туда, «куда и звезды даже не светили», было подавлено чувственностью, и «двуспальная кровать» погребла влюбленных «в одной могиле».

3 DOMBROVSKIJ, Ju.: Fakul'tet nenužnych veščej. Moskva, 1989, s. 508-509. 
Сонет «Надпись на фото» запечатлевает общение с любимой, отъединенной от героя принудительной силой («Моя тоска вступила в год седьмой»). Герой, томящийся в лесах Между Осетрово и Тайшетом, в своих грезах признается любимой: «Ты мне была и счастьем, и судьбой, / И сумерком, и ясностью рассвета». Успокоение он черпает в мысли, что любимая женщина отдалена от опасных мест: «...Бог тебя упас / От рук моих и от петли на ветке».

На смысловой конкретике построено стихотворение «Солдатзаключенной». Бывший армеец, ставший охранником лагеря, ругает то черное дело, которым его принудили заняться: «Это я своим долгом проклятым / Дотянулся к страданьям твоим». Деяния, связанные с насилием над женской природой / «Что обидели люди девчонку / И не будут они прощены!», объявляются поруганием мира и отрицанием высшего смысла жизни: «Не с того ли моря беспокойны, / .. / И столетья уносит в воронку, / И величья проходят, как сны...». Автору свойственно доосыслять бытовую конкретику и встраивать ее в жизнь земли и вселенной.

Никакие противопоказанные искусству условия не способны отлучить Домбровского от поэзии. Оригинальную параллель к стихотворению М. Ю.Лермонтова «Выхожу один я на дорогу» представляет стихотворение «Мария Рильке». При наличии лагерного пейзажа уместен иронический перепев: «Выхожу один я из барака, / Светит месяц, желтый, как собака, / И стоит меж фонарей и звезд / Башня белаядежурный пост». Напарником поэта в лагере оказывается профессор-филолог из Берлина, декламирующий на немецком языке строку из немецкого классика XX века Рильке: «Und Eone redet mit Eone». Герой сближает себя с иностранным заключенным в области культурных интересов: «Мне ведь тоже светят звезды эти / Из стихов, неведомых ему» (имеется в виду лермонтовское стихотворение «Выхожу один я на дорогу»). Два интеллигентных человека объединены участью социальных изгоев: «Мертвых звезд рассеянное тело - / Вот итог судьбы твоей, моей...». Тот, который делит с товарищем «огонь и тьму», тоже мечтает выйти на светлую дорогунавстречу гармонии, выраженной Лермонтовым: «Что ж мы ждем? Пустыня внемлет Богу, / И звезда с звездою говорит...».

Поэтические миниатюры Домбровского сплошь событийнытак проявляет себя в стихах прозаик. Страшное стихотворение «Наседка» содержит рассказ о том, как сокамерники наказали смертью доносчика, делившего с ними тюремное помещение. Для писателя предательство и доносительствонепростимый грех. Говоря из желанного будущего, когда исчезнут тюремные решетки и обновится земля, он утверждает, что и тогда предателей будут казнить самым безжалостным образом. И в этом непрощении предательства, с его точки зрения, заключена мудрость жизни. 
Автор нескольких романов Домбровский пишет также стихотворение, озаглавленное «Вступление к роману «Факультет ненужных вещей». Сюжет подключен к повествованию о пережитом с опорой на скупые, но выразительные детали. Привезли героя «на самый, самый край земли», где он проживает черные, пустые дни, неотличимые один от другого. Заключенных он называет «бойцами неведомой войны» с нацеленными на них ружьями. Автор начинает рассказ про «справедливый суд», который должен снять вину со страдальцев поневоле («Печален будет мой рассказ. / Два раза люди не живут...»).

Живя в тюремном аду, он неустанно воспитывает в себе волю и готовность к поединку со злом. Дерзкий авторский вызов на единоборство звучит в стихотворении, давшем заглавие книге, «Меня убить хотели эти суки». Лирический герой уверен, что никогда не откажется от действенной самозащиты при вражеском нападении. Его самозащита от нападающих в данном случае удалась и подтвердила веру в себя («И вот таким я возвратился в мир...»). Готовность отстаивать собственную правоту в столкновениях с агрессивными чужаками сформирована в нем временем торжествующего насилия.

Вызов кровавому Двадцатому веку прочитывается в стихотворении «Генерал с подполковником вместе...»: «Боже правый, уж скоро полвека / На земле человек, как калека...” / В Освенцимах при радостных криках / Истребляешь ты самых великих...». Неприятие поэта вызывают часто замечаемые им подмены, которые также являются приметами жестокого века: «В час, когда догорает эпоха, / Для чего ты прислал скомороха?..». Жертвы с достойными именами не желают быть поставленными в один ряд с водевильными персонажами, подобными «генералу с подполковником вместе»: «Отнимай нашу честь, наше имя, / Но не делай нас, Боже, смешными!» Неприятие подмен в любом обличииодин из лейтмотивов в поэзии Домбровского.

Не только способность любить и сражаться за свои принципы поддерживает дух Домбровского-арестанта. Он надеется и на чудо Божественного пришествия. На Колыме, в лагере, зимой 1940 года было написано стихотворение «Даже в пекле надежда заводится...». Лирический говоритель представляет себе нечто невероятное: появление в этих адских местах Богородицы, окруженной серафимами. Поверив в невероятное зрелище, он прозревает неминуемый конец притеснителей: «сволочь земли» превращается в «планетарную пыль», и открываются «двери хрустальные» «в трансцендентные небеса». В завершающих строках царит молитвенное настроение персонажаблагословение Божьей Матери: «Да святится имя твое!»

В поэзии Домбровского образные параллели, содержащие вызов царящему насилию, захватывают Космос и Святое Писание. 
Отличается по эмоциональному настрою миниатюра «Надпись на книге», где выясняется самочувствие персонажа в его позиции по отношению к социальному злу: «Я не просил иного рая / Помимо ада моего». Он готов вынести все ужасные не заслуженные им испытания в надежде на собственную нравственную закалку и на грядущую победу добра: «Был пепел жирен, дым был черен, / И дым, и дождь который год! / Но неужель из этих зерен / Уже ничто не прорастет?» Упование на будущее проникает в стихотворение «Мыши»: «Жизнь для меня отыщет оправданье / И в прозе дней, и в музыке стиха».

Заглавие стихотворения «Песня, которую мы пели в лагере, спалив барак усиленного режима в 1952 году» больше подходит для прозаического сочинения. Конец текста содержит вольный перепев русской народной песни: «Ты гори, моя лучинушка, пылай!». Создатель «Песни» призывает сжечь все лагерные постройки и мечтает о грандиозном пожаре, в котором должны сгореть все без исключения притеснители невинных страдающих людей.

Текстом, обобщающим образ авторизированного героя, безусловно остается стихотворение 1940 года «Пока этожизнь...». Живя в аду ледяной Колымы, Домбровский напрягает все силы для преодоления нескончаемого, жуткого настоящего. Поддержкой для него остается осознание собственной возможности пересоздания пережитого в поэзии: «Я жду, что зажжется Искусством / Моя нестерпимая быль».

Единственная в литературном наследии Юрия Домбровского книга стихотворений «Меня убить хотели эти суки» была издана в 1997 году в Москве Историко-литературным обществом «Возвращение». Составитель книги и автор вступительной статьивдова писателя Клара Турумова-Домбровская. Как сообщает Клара, осенью 1960 года, после отъезда из Алма-Аты в Москву, Юрий Домбровский выслал той, которая еще не стала его женой, «подборку своих лагерных стихов»с пояснением: «Моя запретная тетрадь одной откровенной девочке» (с. 7). Книга томилась в архивах послушных властям издательств 37 лет, пока наконец не была опубликована с дополнениями в виде фрагментов писем к Кларе.

Соберем воедино то, чем может быть обогащен сегодняшний читатель поэтической книги, пришедшей к нему намного позже ее написания. Литератор, проживший в статусе арестанта более двадцати лет, находясь на Колыме накануне и в начальный период Отечественной войны, пожелал связаться с читательской аудиторией и вербализовать свой жизненный опыт с привлечением рифм и ритмики.

Вид тюремной камеры и лагерного баракапривычная обстановка интерьера в его стихотворениях. А вне сторожевых постов и проволоки заграждений остается северный мрак и ледяная пустыня Колымы. Внутри лагерябесконечная 
вереница однообразных дней, проводимых в неволе. Разнообразие создают обитатели камер,этим характерологическим контрастом, привносимом различными людьми, и занимается искусство. Герой поэзии ДомбровскогоЧеловек с большой буквы с его интеллектом, эмоциями и каждодневно тренируемой волей. Такой человек видит смысл своего существования в неустанном противостоянии царящему насилию. Вдохновляет его и вера в то, что страдания, переплавленные в золото поэзии, станут принадлежностью вечного Искусства.

Как же проявляет себя герой поэзии Домбровского в пестрой мозаике своих рождающихся в неволе стихотворений? Из земного мрака он пытается пробиться в сияющее пространство мироздания, к звездам, к «осколкам комет». Этим повторяющимся порывом от лагерного топоса к просторам мироздания объясняется развитие мотивов космизма в его арестантских стихах. В недвижном настоящем он спасается также уроками истории и темами мирового искусства. Неустанно занимается творец и вечной темой любви, объявляя себя сторонником любви космической. Страдающего, униженного человека герой Домбровского берет под свою защиту. Известен писатель-узник и своей нетерпимостью к предателям и доносчикам. Ироническое отношение вызывают у него литераторы-гедонисты, признающие, как нечто ценное, лишь собсвенные эгоистические удовольствия. Двойное сочувствие испытывает он к интеллигентамжертвам системы, насильственно оторванным от творчества. Неослабевающий протест вызывают у него оценочные подмены, когда меняются местами истинное и ложное и тем самым разрушается скала моральных ценностей, утвержденных веками существования человечества и Святым Писанием. Личным жизненным опытом пишущий доказывает, что для него высшей ценностью остается неписанный нравственный закон жизни.

Структура цикла стихотворений прозрачна: руководит поэтической речью классический ямб. В семантике обнаруживается следование традициям отечественной гражданской поэзии, тональности и позиции Н. А. Некрасова. Современного автора продолжает вдохновлять некрасовская сентенция «Поэтом можешь ты не быть, но гражданином быть обязан». Обобщения в стихах основываются на непосредственных личных впечатлениях, на бытовых и сюжетных деталях. Ничем не замутненная логика смысла зовет к превозможению слабостей физического характера. Личность автора находится в гармонии с качествами лирического героя его стихов. Гармоничность соотношения слово-дело заставляет читателя испытывать полное доверие к поэту и рождает желание извлечь для себя уроки из его опыта. Оказывается, жизненные уроки не стареют, а донесенные поэтическим словом они способны заражать и согревать душу людей, принадлежащих к XXI-му веку, неведомых автору. 
Получила ожидаемую трагическую завершенность и судьба литератора. Не получив одобрения советской цензуры, он переслал свой «антисоветский» роман «Факультет ненужных вещей» за границу. Роман был напечатан на русском языке в Париже в издательстве «YMCA-PRESS» (1978). Расплата за дерзость пришла очень скоро. Домбровский получал угрозы по телефону, пока группа неопознанных бандитов не напала на него поблизости от Центрального Дома Литераторов. Незащищенного человека избивали продолжительно, с нацеленностью на смертельный исход. Лежа в больнице, писатель с отрадным чувством перелистывал свою последнюю книгу. Наличие опубликованного романа помогало бороться с недугом, но смерть от кровоизлияния внутренних органов настигла его в том же 1978 годуна пороге семидесятилетия.

\section{Литература:}

OKUDŽAVA, B.: Zamok nadeždy. Moskva, 2008.

DOMBROVSKIJ, Ju.: Menja ubit' choteli èti suki. Moskva, 1997.

DOMBROVSKIJ, Ju.: Fakul'tet nenužnych veščej. Moskva, 1989.

\section{About the author}

Irina Zakharieva, "St. Kliment Ohridski" University of Sofia, Sofia, Bulgaria, irina_zaharieva@abv.bg 